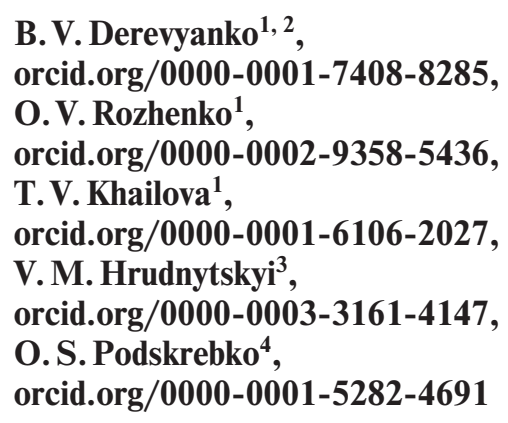

1 - Donetsk Law Institute of the Ministry of Internal Affairs of Ukraine, Kryvyi Rih, Ukraine, e-mail: del2000@i.ua 2 - Academician F. H. Burchak Scientific Research Institute of Private Law and Entrepreneurship of the National Academy of Legal Sciences of Ukraine, Kiev, Ukraine 3 - State Institution of Higher Education "Donetsk National Technical University”, Pokrovsk, Ukraine 4 - National Aviation University, Kyiv, Ukraine

\title{
STRATEGIC ENTERPRISE MANAGEMENT BASED ON THE MODELING OF ITS ECONOMIC SECURITY
}

Purpose. Justification of the methodological approach to the strategic management of reserves for the growth of economic security of enterprises and the provision of appropriate recommendations for this purpose (by the example of METINVEST HOLDING LLC, mining enterprises of the Kryvyi Rih iron-ore basin).

Methodology. A system of the following general scientific and special methods was used to achieve the research goal: mathematical and statistical methods - to assess the economic security of selected enterprises; methods of correlation and regression analysis - to form a system of indicators of the greatest impact on the economic security of the enterprise; econometric modeling methods - to predict the value of the integrated indicator of economic security of the enterprises; structured system method - to determine the reserves of economic security growth for each business structure; matrix methods - to form a strategic field and determine the place of each of the enterprises under study within this field.

Findings. The authors have analyzed the dynamics of the economic security of mining enterprises in the Kryvyi Rih iron-ore basin from 2014 to 2018. Multivariate correlation and regression models have been built that allow determining the calculated (maximum possible) value of the integral indicator of the economic security of the enterprises under consideration. After comparing a defined (actual) and calculated value of economic security of the studied elements of the economic security system, its growth reserves for each business structure have been determined. The economic security trend of each mining enterprise in the Kryvyi Rih iron-ore basin until 2021 has been determined, which is characterized by an upward or downward slope of the economic safety values of the enterprises under consideration, predicted by the models and the prospect of achieving the maximum value of it. The resulting characteristics of the economic security value of enterprises predicted based on the trending models make it possible to build a strategic field of basic strategies according to Michael H. Mescon and determine the position of each enterprise within it.

Originality. The authors offer a methodological approach to the strategic management of the growth reserves of the economic security of the enterprise, which is defined as a result of the study that is based on the improvement of the instrumental apparatus, which, in contrast to the existing ones, allows synchronizing both temporal and spatial parameters, significantly increasing the efficiency of managerial decision-making.

Practical value. The methodological approach to the strategic management of the use of reserves for the growth of the economic security of the enterprise allows synchronizing the strategic management of the enterprise with the modeling of the economic security level. This ensures the economic security of the enterprise to a fuller extent.

Keywords: economic security, mining enterprise, growth reserves, level trend, basic strategy, management

Introduction. The study on the rate of changes in the rating assessment of Ukraine according to the Global Competitiveness Index and its components [1], which in the period since the beginning of the anti-terrorist operation in the east of Ukraine has so far been carried out by integrating the threecomponent methodology, which had been used until 2017, and the four-component methodology, which has been used since 2018, demonstrates the unfavorable management environment for Ukrainian business entities, the influence of the factors of which in the modern geopolitical conditions of integration and globalization prevails over the internal factors.

The pace of changes in the rating assessment of the Global Competitiveness Index of Ukraine in comparison with the previous year for 2015-2019 makes it possible to formulate the problem of failure to achieve a stable level of the Global Competitiveness Index of Ukraine, and the need to improve the tools for the strategic management of microeconomic systems based on ensuring their economic security.

Studies on the economic development of industrial production in Ukraine in the context of regions for 2018 as compared to 2017 according to the Ministry of Economic Development and

(C) Derevyanko B. V., Rozhenko O. V., Khailova T. V., Hrudnytskyi V. M., Podskrebko O. S., 2021
Trade of Ukraine show that Dnipropetrovsk region is one of three, in which the share in the total volume of industrial products sold is the largest in Ukraine, together with Zaporizhzhia region and Donetsk region [2]. In these three regions, more than half of industrial production accounts for the processing industry, and a significant part (about a quarter) accounts for the extractive industry solely in Dnipropetrovsk region and Donetsk region. The analysis of the economic development of the industrial production of these three leading regions is essentially revealed by the dynamics of production. In the extractive industry, this indicator is the largest in Donetsk region, in the processing industry - in Zaporizhzhia region, the dynamics of production is the smallest in Dnipropetrovsk region.

According to forecasts of the economic and social development of Ukraine for 2020-2022, the main projected macroindicators of the economic and social development of Ukraine for 2020-2022 demonstrate an improvement in the price terms of trade, in particular for base metals and iron ore [3].

Thus, the analysis of the external environment for economic management at the meso-, macro- and global levels demonstrates the relevance of the set scientific problem and the representativeness of the selected enterprises for research.

Literature review. Unsolved aspects of the problem. Management of any entrepreneurial structure in modern turbody- 
namic conditions for the implementation of integration processes requires the use of mechanisms to ensure their economic security and, according to the scientific work by M. Leshchinsky, remains decisive for determining modern determinants of security (in a multipolar system and an array of asymmetric threats), as well as the role of economic science in making strategic decisions [4]. One of the most challenging problems of successful functioning of business entities is the search for an effective management solution in the future, i.e. forecasting the level of economic security of business entities, which, in conditions of market uncertainty, acts as a tool to minimize it.

Forecasting, as one of the conceptually basic management functions, involves the use of appropriate tools for economic and mathematical modeling with varying degrees of formalization and the adequacy of conclusions about the development of the process in the future. According to Scott Pardo, "many methods may be employed to either narrow the field or provide a predictive model when it is very difficult to select or eliminate any regressors" [5]

"The concept of a strategic experiment is a key success engine for many companies and a vital potential for every firm seeking a differentiated competitive advantage. Four key points of a strategic experiment are design, framework, organization, and control" [6]. These key points are used for the strategic experiment in this article, through the disclosure of management functions and the existing system of methods.

The basis of this research is the enterprises, which were launched as integral property complexes more than half a century ago. During the period of operation, the enterprises under consideration have changed many of their economic and legal characteristics (the creation and ownership of capital in the first place, which is a derivative parameter of their management), but the technical and technological characteristics have not been radically changed and are considered in modern society as regressive, taking into account ecological, geographic, sociodemographic and other parameters. Taking this into account in scientific and practical circles, both at the level of state regulation and the level of corporate governance, an issue constantly arises about the need, expediency of capital investments in these property objects, and the sources of their financing. According to the research by Staniewski M., Szopiński T., Awruk K. "People who undertake business activity to generate greater earnings/accumulate wealth are more likely to use their capital or repayable funds" [7]. Studies using the example of construction companies in the regions of Poland, which also need constant innovation in management and operational aspects, demonstrate that "analysis of the innovative activities of these companies by location shows that, in turn, the entities operating in the regions which have less economic development and are less attractive in terms of investment, are more innovative" [8].

In the specialized literature, the system of strategic management of an enterprise based on modeling of its economic security remains insufficiently studied. At the same time, the defining aspects of the problem were considered in the works by domestic and foreign scientists in the field of economics, management, and mathematical statistics, namely: L. Endress determined that security and economic well-being is achieved by observing three pillars of sustainable development: the adoption of an integrated, dynamic systemic approach to resource modeling [9].

O. Reznik noted that "the proper protection of the financial security of the state from internal and external threats is possible only in the case of quality management of the financial and economic sphere" [10].

The work by Dr. Csath Magdolna et al. emphasizes that the importance of economic security "can be divided into the following two parts: security of ordinary operation and security of long-term development... Since the means of altering them are quite difficult and slow, developing them requires a continu- ous, well-considered, conscious strategy" [11]. However, there is still no general concept of synchronizing the modeling of the economic security of enterprises with the system of their strategic management. In this scientific work, economic security is studied in the coordinate system of socio-economic processes, the authors argue that "the importance of economic security has increased significantly in recent decades. It can be separated into the following two parts: security of ordinary operation and security of long-term development. In this article, we are going to deal with the latter, especially the so-called soft factors which make up the basis of it. These factors are human capital, social capital, and territorial capital [11].

The next work investigates the economic security of Polish power plants as microeconomic systems that play an important role in the national economy; their efficiency is associated with the performance of many other companies, so that "an analytical model is presented that measures the economic security of a company engaged in energy production - a company, which is of strategic importance for the national economy. The model uses macroeconomic variables, variables describing commodity prices and legal/political stability in the country, as well as selected financial indicators" [12]. Therefore, the authors chose the mining and manufacturing sector for the metallurgy of Kryvyi Rih as the basis of the study, which acts as a region-forming and system-forming for both the national and world economies, which will allow the enterprises of the selected group to develop and timely neutralize threats.

The scientific work demonstrates the impact of critical infrastructure on the economic security of an enterprise by the example of the European Union, the Czech Republic, and Slovakia: "attention is paid to the individual links between critical infrastructure elements and the enterprise. Subsequently, the economic security of the enterprise, the main factors that participate in its creation and the threats that violate it, are discussed with an emphasis on critical infrastructure failure" [13]. In the context of this study, these results are important because the economically safe operation of the enterprises under consideration presupposes the presence of developed production infrastructure.

Development sustainability as one of the characteristics of the economic security of an enterprise was investigated by G. Bachev. The result of the research involves "different personal, market, institutional, and other factors identified for improving sustainability" by the example of agricultural enterprises in Bulgaria [14].

Purpose. Substantiating a methodological approach to the strategic management of the reserves for the growth of the economic security of an enterprise and giving appropriate recommendations for its provision to a fuller extent (by the example of the mining enterprises of METINVEST HOLDING LLC in the Kryvyi Rih iron-ore basin).

Results. Modeling, as one of the subfunctions of management, in particular strategic management, plays an exceptional role in achieving its effectiveness. The calculations, according to the methodology of enterprise management based on ensuring economic security [15], provided the results of assessing the level of economic security of mining enterprises in the Kryvyi Rih iron-ore basin belonging to the Metinvest mining and metallurgical group of companies (Fig. 1).

The visualization of the data obtained allows concluding that the growth rates of the economic security of enterprises, whose activities are being investigated, are decreasing. This confirms the relevance of the selected scientific problem and demonstrates the need for the development and implementation of appropriate management actions, primarily from a strategic perspective. Thus, the greatest decrease in the level of economic security is observed at Ingulets Iron Ore Dressing Works PJSC, the greatest stability and lowest level of economic security - at Central Iron Ore Dressing Works PJSC.

The basis of the regulatory and managerial influence at any level of the socio-economic system is the identification of fac- 


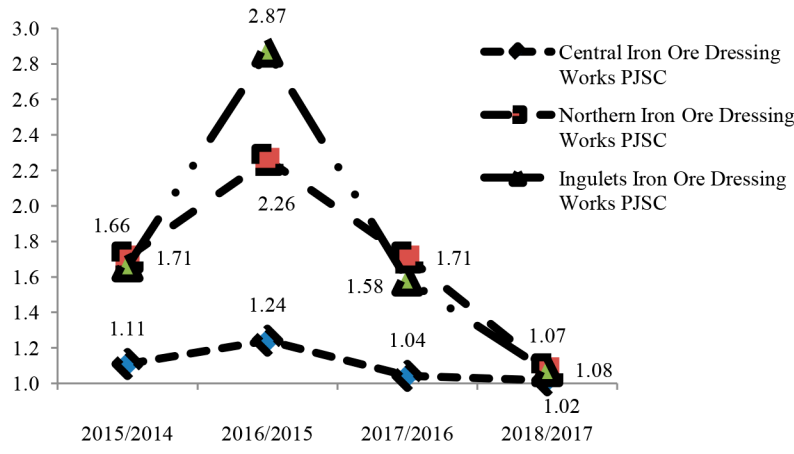

Fig. 1. Index of changes in the level of economic security of the mining enterprises of Metinvest Holding LLC in the Kryvyi Rih iron-ore basin $[15,17,18]$

tors that most strongly affect the change in the effective indicator. At the microeconomic level, this study used the method of multivariate regression analysis and built adequate correla- tion-regression models of the level of economic security of the mining enterprises of METINVEST HOLDING LLC in the Kryvyi Rih iron-ore basin according to second-level local components, which is shown in Table 1.

In the equations, the variables $X_{1}$ and $X_{2}$ are indicators from the system of the assessment of the level of economic security of the enterprises under study, which have the highest degree of correlation with the obtained integral indicator of the economic security of the enterprise.

The multifactor correlation-regression models were used to form the calculated value of the integral indicator of economic security for the local components of the first level, which allowed determining the reserves for the growth of the economic security of the enterprises under consideration (Table 2).

According to Table 2, it is clear that there are reserves for the growth of the level of economic security of the enterprises under consideration, but their size is not unambiguous, including in the context of local components of the first level. Ingulets Iron Ore Dressing Works PJSC has the largest reserves for the growth of the level of economic security $(0.15)$, the reserves at the other two enterprises are found to be lower than 0.1.

Multivariate correlation-regression models of economic security of the selected enterprises [16-18]

\begin{tabular}{|c|c|c|}
\hline $\begin{array}{l}\text { Component of the economic security } \\
\text { of a second-level enterprise }\end{array}$ & $\begin{array}{l}\text { Multivariate correlation-regression } \\
\text { models }\end{array}$ & Variables \\
\hline Security of labor resources & $\begin{array}{l}R 2=0.8511 \\
M l r=0.907-0.053 X_{1}+0.0184 X_{2}\end{array}$ & $\begin{array}{l}X_{1}-\text { the average wage/minimum wage ratio at the enterprise } \\
X_{2}-\text { labor resources efficiency }\end{array}$ \\
\hline Security of financial resources & $\begin{array}{l}R 2=0.9734 \\
M f r=0.0775+0.671 X_{1}+0.401 X_{2}\end{array}$ & $\begin{array}{l}X_{1}-\text { financial stability coefficient } \\
X_{2}-\text { equity efficiency }\end{array}$ \\
\hline Security of tangible resources & $\begin{array}{l}R 2=0.8846 \\
M t r=0.2754+0.2271 X_{1}+0.401 X_{2}\end{array}$ & $\begin{array}{l}X_{1}-\text { return on assets } \\
X_{2}-\text { efficiency of tangible resources }\end{array}$ \\
\hline Security of intangible resources & $\begin{array}{l}R 2=0.9115 \\
\text { Mir }=0.0014+0.0061 X_{1}-0.0131 X_{2}\end{array}$ & $\begin{array}{l}X_{1}-\text { return on tangible assets } \\
X_{2}-\text { efficiency of intangible resources }\end{array}$ \\
\hline Management security & $\begin{array}{l}R 2=0.9574 \\
\mathrm{Mm}=0.6422+0.6138 X_{1}+0.4117 X_{2}\end{array}$ & $\begin{array}{l}X_{1}-\text { efficiency of current assets } \\
X_{2} \text { - efficiency of fixed assets } \\
\end{array}$ \\
\hline Marketing security & $\begin{array}{l}R 2=0.9242 \\
M m a=0.5293+0.3889 X_{1}+0.8763 X_{2}\end{array}$ & $\begin{array}{l}X_{1}-\text { efficiency of distribution costs } \\
X_{2} \text { - commercial efficiency }\end{array}$ \\
\hline Production security & $\begin{array}{l}R 2=0.9613 \\
M p=0.9368-0.8903 X_{1}+0.15314 X_{2}\end{array}$ & $\begin{array}{l}X_{1}-\text { production efficiency } \\
X_{2} \text { - equity turnover ratio }\end{array}$ \\
\hline
\end{tabular}

Results of determining the growth reserves of the economic security of selected enterprises [15, 16-18]

\begin{tabular}{|c|c|c|c|c|c|c|c|c|c|c|}
\hline 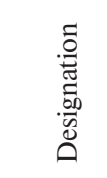 & 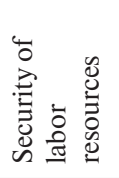 & 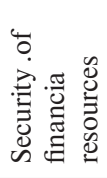 & 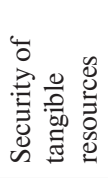 & 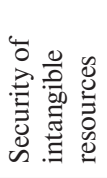 & 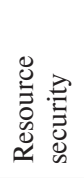 & 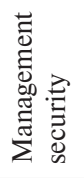 & 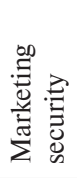 & 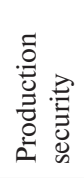 & 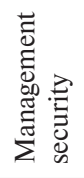 & 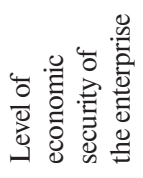 \\
\hline \multicolumn{11}{|c|}{ Central Iron Ore Dressing Works PJSC } \\
\hline I act. & 0.78 & 0.84 & 0.83 & 0.91 & 0.84 & 0.83 & 0.71 & 0.83 & 0.79 & 0.81 \\
\hline I calc. & 0.80 & 0.88 & 0.89 & 0.98 & 0.88 & 0.93 & 0.98 & 0.86 & 0.92 & 0.90 \\
\hline Reserve & 0.02 & 0.04 & 0.06 & 0.07 & 0.05 & 0.10 & 0.27 & 0.03 & 0.13 & 0.09 \\
\hline \multicolumn{11}{|c|}{ Northern Iron Ore Dressing Works PJSC } \\
\hline I act. & 0.90 & 0.92 & 0.81 & 0.65 & 0.81 & 0.80 & 0.93 & 0.89 & 0.87 & 0.84 \\
\hline I calc. & 0.91 & 0.98 & 0.96 & 0.73 & 0.89 & 0.82 & 0.93 & 0.92 & 0.89 & 0.89 \\
\hline Reserve & 0.01 & 0.07 & 0.15 & 0.08 & 0.08 & 0.02 & 0.00 & 0.03 & 0.02 & 0.05 \\
\hline \multicolumn{11}{|c|}{ Ingulets Iron Ore Dressing Works PJSC } \\
\hline I act. & 0.84 & 0.59 & 0.25 & 0.28 & 0.43 & 0.28 & 0.21 & 0.27 & 0.25 & 0.33 \\
\hline I calc. & 0.85 & 0.62 & 0.79 & 0.35 & 0.62 & 0.33 & 0.44 & 0.34 & 0.37 & 0.48 \\
\hline Reserve & 0.004 & 0.04 & 0.54 & 0.07 & 0.19 & 0.05 & 0.23 & 0.07 & 0.12 & 0.15 \\
\hline
\end{tabular}


Modeling of the economic security of mining enterprises of METINVEST HOLDING LLC in the Kryvyi Rih iron-ore ba$\sin$ is based on the results of assessing the level of economic security of the respective enterprises carried out using the MS Excel function "Trend" (Fig. 2). As can be seen from Fig. 2, the obtained trends in the economic security of the mining enterprises of METINVEST HOLDING LLC in the Kryvyi Rih iron-ore basin have a different angle of inclination, which suggests a corresponding value of the specific indicator in the future. Thus, Northern Iron Ore Dressing Works PJSC is predicted to be the first to achieve the maximum level of economic security. Central Iron Ore Dressing Works PJSC is predicted to reach the same position in a two-year perspective; for Ingulets Iron Ore Dressing Works PJSC, the results of modeling the economic security predict that by 2021 the value will double (from 0.329 to 0.635 ).

Modeling the level of economic security of the mining enterprises of METINVEST HOLDING LLC in the Kryvyi Rih iron-ore basin, which was carried out based on the correlation-regression analysis and trend models, acts as a factor that requires an appropriate management impact on this indicator, in particular, in the strategic perspective.

To implement strategic management, the indicator of which is the result of modeling the level of economic security (using the example of mining enterprises in the Kryvyi Rih iron-ore basin), it is proposed to use the classical portfolio of basic strategies according to Michael H. Mescon, Michael Albert, Franklin Khedouri (1988), namely: limited-growth strategy, growth strategy, retrenchment strategy, combination strategy. Thus, the strategic field and the place of selected enterprises therein have the following form (Fig. 3).

Thus, based on the results of constructing a matrix field, according to the indicator of modeling the level of economic security of an enterprise, and determining the location of each enterprise studied in this field, we conclude that Northern Iron Ore Dressing Works PJSC should choose a strategy of limited growth, and Central Iron Ore Dressing Works PJSC and Ingulets Iron Ore Dressing Works PJSC are advised to use a basic growth strategy.

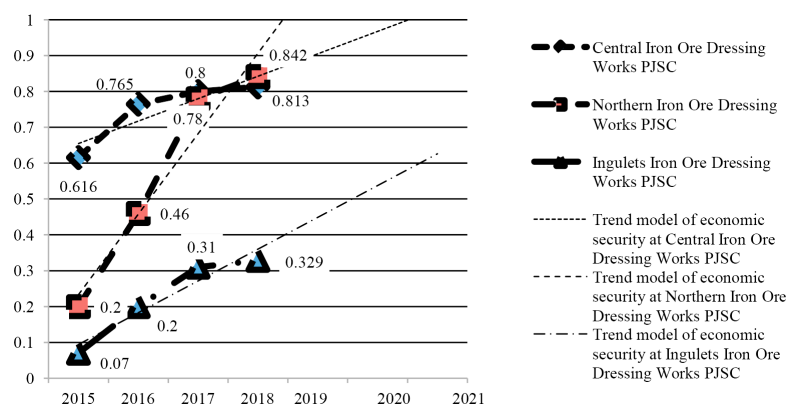

Fig. 2. The trend of the level of economic security of the mining enterprises of METINVEST HOLDING LLC in the Kryvyi Rih iron-ore basin [16-18]

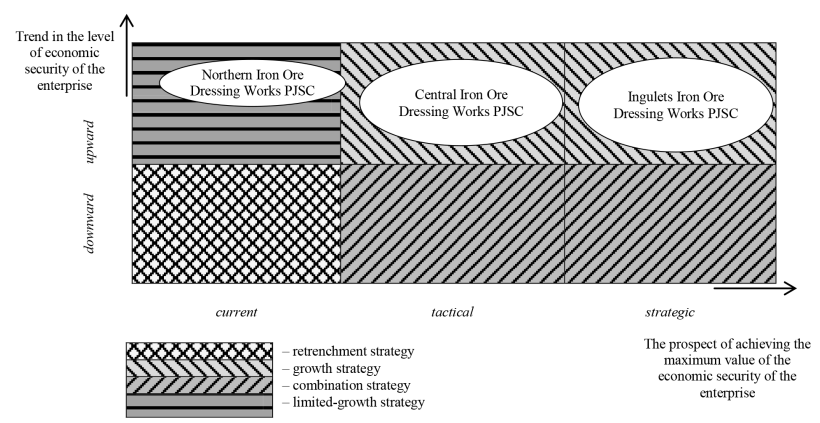

Fig. 3. The strategic field and the place of the selected enterprises therein
Modeling the level of economic security of entrepreneurial structures under conditions of uncertainty and instability of the economic environment acts as a vector of their strategic management, as a border between opportunities and limitations. Therefore, an important area of the economically secure transformation of the mining enterprises of the Kryvyi Rih iron-ore basin is the synchronization of the strategic management system with the models for forecasting the level of their economic security.

Thus, the strategic management of an enterprise based on modeling the economic security acts as traffic for change in the existing entrepreneurial position, in particular, to the target one (i.e. a modeled forecast), is characterized by an appropriate set of strategic alternatives and a vector of policy development and tactics for their implementation.

Conclusions. The study has proven the non-exclusive importance of modeling in strategic management. It has been found that changes in the level of economic security of the mining enterprises of METINVEST HOLDING LLC in the Kryvyi Rih iron-ore basin are negative, the largest change in absolute value is observed for Northern Iron Ore Dressing Works PJSC. Multivariate correlation-regression models with local components and general economic security of the enterprise have been constructed. Their adequacy has been mathematically proven based on factors that have a strong connection with the performance indicator. By comparing the calculated value according to the correlation-regression model and obtained through the use of the method for determining the integral indicator of economic security, in the context of local and general components, the reserves of its growth were determined for each business structure. A trend line of economic security of each mining enterprise of METINVEST HOLDING LLC in the Kryvyi Rih iron-ore basin was built. Based on the nature of the resulting trend (downward or upward) and the angle of its slope (current, tactical or strategic perspective of achieving the maximum value of the economic security of the enterprise), the strategic field of basic strategies according to Michael $\mathrm{H}$. Mescon has been built, which took the form of $2 * 3$, i.e. six quadrants, characterizing the corresponding basic strategies. Each of the enterprises under consideration was positioned on it, namely: Northern Iron Ore Dressing Works PJSC took a limited-growth strategy, Central Iron Ore Dressing Works PJSC and Ingulets Iron Ore Dressing Works PJSC - growth strategy.

Thus, the synchronization of the strategic management of an enterprise with modeling the level of economic security is determined by the basic nature of the implementation of the economic process for its management, but subject to the results of scientific research using econometric methods of modeling and forecasting. The implementation of such strategic management of an enterprise precisely according to the indicator of modeling the level of economic security implies the constant improvement of business processes at all levels of the socio-economic system, which will contribute to the maximum use of the existing opportunities of business entities, i.e. certain reserves for its growth, and the elimination of restrictions (the elimination of existing threats).

The conducted research demonstrates the need to develop a mechanism for managing identified reserves, which is a prospect for further research.

\section{References.}

1. Global Competitiveness Report 2019. The World Economic Forum. Retrieved from https://www.weforum.org/reports/ global-competitiveness-report-2019.

2. Ministry of Economic Development and Trade of Ukraine (2018). Economic development in terms of regions of Ukraine (following the results of 2018). Retrieved from http://www.me. gov.ua.

3. On Approval of the Forecast of Economic and Social Development of Ukraine for 2020-2022. Resolution of the Cabinet of Ministers of Ukraine No. 555 dd. May 15, 2019. Retrieved from https://zakon.rada.gov.ua/laws/show/555-2019-\%D0\%BF. 
4. Leszczyński, M. (2017). The economic dimension of security. Zeszyty Naukowe Polskiego Towarzystwa Ekonomicznego w Zielonej Górze, 6, 83-89. https://doi.org/10.26366/PTE. ZG.2017.82.

5. Pardo, S. (2020). Models, Models Everywhere...Model Selection. In: Statistical Analysis of Empirical Data, (pp 121-160). Springer, Cham. https://doi.org/10.1007/978-3-030-433284 _11.

6. Ammar, O. (2014). L'approche des fonds d'investissement dans l'expérimentation stratégique du Business Model. $\mathrm{Hu}$ manisme et Entreprise, 316(1), 47-66. https://doi.org/10.3917/ hume.316.0047.

7. Staniewski, M., Szopiński, T., \& Awruk, K. (2016). Setting up a Business and Funding Sources. Journal of Business Research, 69(6), 2108-2112 https://doi.org/10.1016/j. jbusres.2015.12.016.

8. Staniewski, M.W., Nowacki, R., \& Awruk, K. (2016). Entrepreneurship and innovativeness of small and medium-sized construction enterprises. International Entrepreneurship and Management Journal, 12(3), 861-877 Retrieved from https:// link.springer.com/article/10.1007/s11365-016-0385-8.

9. Endress, L. H. (2015). Scarcity, Security, and Sustainable Development. Sustainable Economic Development. Resources, Environment and Institution, 49-66. https://doi.org/10.1016/ B978-0-12-800347-3.00003-0.

10. Reznik, O., Getmanets, O., Kovalchuk, A., Nastyuk, V., \& Andriichenko, N. (2020). Financial security of the state. Journal of Security and Sustainability Issues, 9(3), 843-852. https://doi.org/10.9770/jssi.2020.9.3.

11. Dr. Csath, M., Fási, C., Nagy, B., Pálfi, N., Taksás, B., \& Vinogradov, S. (2019). Soft Factors of Economic Security. Academic and Applied Research in Military and Public, 18, 117129. https://doi.org/10.32565/aarms.2019.2.7.

12. Niedziółka, D., \& Czyżak, P. (2017). The economic security of power plants. Web of Conferences. Retrieved from https://www.e3s-conferences.org/articles/e3sconf/ pdf/2017/02/e3sconf ef2017 01007.pdf.

13. Strelcova, S., Rehak, D., \& Johnson, D. E. A. (2015). Influence of critical infrastructure on enterprise economic security. Communications, 1, 105-110. Retrieved from https://www. researchgate.net/publication/271941856.

14. Bachev, H. (2017). Sustainability of Bulgarian farming enterprises during European Union common agricultural policy implementation. Journal of Applied Economic Sciences, 12(2), 422-451.

15. Rozhenko, A. V. (2017). Strategic management of the enterprise based on ensuring its economic security. Economics and Finance, (3), 90-97.

16. Annual Information. Ingulets Iron Ore Dressing Works (n.d.). Retrieved from https://smida.gov.ua/db/participant/00190905. 17. Annual Information. Northern Iron Ore Dressing Works. Retrieved from https://smida.gov.ua/db/participant/00191023.

18. Central Iron Ore Dressing Works. Annual Information (n.d.). Retrieved from https://smida.gov.ua/db/participant/00190977.

\section{Стратегічне управління добувним підприємством на основі рівня його економічної безпеки}

\section{Б. В. Деревянко ${ }^{1,2}$, О. В. Роженко ${ }^{1}$, Т. В. Хайлова ${ }^{1}$} В. М. Грудницький

1 - Донецький юридичний інститут МВС України, м. Кривий Ріг, Україна, e-mail: del2000@i.ua

2 - Науково-дослідний інститут приватного права і підприємництва імені академіка Ф. Г. Бурчака Національної академії правових наук України (НАПрН), м. Київ, Україна 3 - Державний заклад вищої освіти «Донецький національний технічний університет», м. Покровськ, Україна 4 - Національний авіаційний університет, м. Київ, Україна
Мета. Обгрунтування методичного підходу до стратегічного управління резервами зростання економічної безпеки підприємства й надання відповідних рекомендацій щодо ії забезпечення в більш повній мірі (на прикладі добувних підприємств Криворізького басейну ТОВ «Метінвест Холдинг»).

Методика. Для досягнення поставленої мети дослідження використана система загальнонаукових і спеціальних методів, а саме: математичні та статистичні методи - для оцінки економічної безпеки підприємств обраної сукупності; методи кореляційно-регресійного аналізу - для формування системи показників найбільшого впливу на економічну безпеку підприємства; методи економетричного моделювання - для прогнозування значення інтегрального показника економічної безпеки відповідних підприємств; системно-структурний метод - для визначення резервів зростання економічної безпеки за кожною підприємницькою структурою; матричні методи - для формування стратегічного поля й визначення кожного з досліджуваних підприємств на ньому.

Результати. У роботі проаналізовані показники динаміки економічної безпеки добувних підприємств Криворізького басейну за 2014-2018 рр. Побудовані багатофакторні кореляційно-регресійні моделі, що дозволяють визначити розрахункове (максимально можливе) значення інтегрального показника економічної безпеки відповідних підприємств. У результаті порівняння визначеного (фактичного) й розрахункового значення економічної безпеки досліджуваних елементів системи економічної безпеки визначені резерви іiі зростання за кожною підприємницькою структурою. Визначено тренд економічної безпеки кожного добувного підприємства Криворізького басейну до 2021 року, що характеризується висхідним або низхідним нахилом прогнозованих за моделями значеннями економічної безпеки досліджуваних підприємств і перспективою досягнення іiі максимального значення. Сформовані характеристики прогнозованого на основі трендових моделей значення економічної безпеки підприємств дозволяють побудувати стратегічне поле базових стратегій за Michael H. Mescon і визначити позицію кожного на ньому.

Наукова новизна. Запропоновано методичний підхід до стратегічного управління резервами зростання економічної безпеки підприємства, що визначено в результаті дослідження, який грунтується на вдосконаленні інструментального апарату, що, на відміну від існуючих, дозволяє синхронізувати як часові, так і просторові параметри, значно підвищуючи ефективність прийняття управлінських рішень.

Практична значимість. Використання методичного підходу до стратегічного управління використання резервів зростання економічної безпеки підприємства дозволяє синхронізувати стратегічне управління підприємством з моделюванням рівня його економічної безпеки. Це забезпечує економічну безпеку підприємства в більш повній мірі.

Ключові слова: економічна безпека, видобувне підприємство, резерви зростання, тренд рівня, базова стратегія, управління

\section{Стратегическое управление добывающим предприятием на основе уровня его экономической безопасности}

\author{
Б. В. Деревянко ${ }^{1,2}$, А. В. Роженко ${ }^{1}$, Т. В. Хайлова ${ }^{1}$, \\ В. М. Грудницкий ${ }^{3}$ А. С. Подскребко
}


1 - Донецкий юридический институт МВД Украины, г. Кривой Рог, Украина, e-mail: del2000@i.ua

2 - Научно-исследовательский институт частного права и предпринимательства имени академика Ф. Г. Бурчака Национальной академии правовых наук Украины $($ НАПрН), г. Киев, Украина

2 - Государственное учреждение высшего образования «Донецкий национальный технический университет», г. Покровск, Украина

3 - Национальный авиационный университет, г. Киев, Украина

Цель. Обоснование методического подхода к стратегическому управлению резервами роста экономической безопасности предприятия и предоставление соответствующих рекомендаций по ее обеспечению в более полной мере (на примере добывающих предприятий Криворожского бассейна ООО «Метинвест Холдинг»).

Методика. Для достижения поставленной цели исследования использована система общенаучных и специальных методов, а именно: математические и статистические методы - для оценки экономической безопасности предприятий выбранной совокупности; методы корреляционно-регрессионного анализа - для формирования системы показателей наибольшего влияния на экономическую безопасность предприятия; методы эконометрического моделирования - для прогнозирования значения интегрального показателя экономической безопасности соответствующих предприятий; системноструктурный метод - для определения резервов роста экономической безопасности по каждой предпринимательской структуре; матричные методы - для формирования стратегического поля и определения каждого из исследуемых предприятий на нем.

Результаты. В работе проанализированы показатели динамики экономической безопасности добывающих предприятий Криворожского бассейна за 2014-2018 гг. Построены многофакторные корреляционно-регрессионные модели, позволяющие определить расчетное (максимально возможное) значение интегрального по- казателя экономической безопасности соответствующих предприятий. В результате сравнения определенного (фактического) и расчетного значения экономической безопасности исследуемых элементов системы экономической безопасности определены резервы ее роста по каждой предпринимательской структуре. Определен тренд экономической безопасности каждого добывающего предприятия Криворожского бассейна до 2021 года, который характеризуется восходящим или нисходящим уклоном прогнозируемых по моделям значениями экономической безопасности исследуемых предприятий и перспективой достижения ее максимального значения. Сформированные характеристики прогнозируемого на основе трендовых моделей значения экономической безопасности предприятий позволяют построить стратегическое поле базовых стратегий по Michael H. Mescon и определить позицию каждого на нем.

Научная новизна. Предложен методический подход к стратегическому управлению резервами роста экономической безопасности предприятия, который определен на основе усовершенствованного методически-инструментального аппарата, что, в отличие от существующих, позволяет синхронизировать как временные, так и пространственные параметры, значительно повышая эффективность принятия управленческих решений.

Практическая значимость. Использование методического подхода к стратегическому управлению использования резервов роста экономической безопасности предприятия позволяет синхронизировать стратегическое управление предприятием с моделированием уровня экономической безопасности. Это обеспечивает экономическую безопасность предприятия в более полной мере.

Ключевые слова: экономическая безопасность, добывающее предприятие, резервы роста, тренд уровня, базовая стратегия, управление

Recommended for publication by Yu. H. Bocharova, Doctor of Economic Sciences. The manuscript was submitted 15.03.20. 